\title{
US Publications (2000-2020) on Muscovite History, 1462-16891
}

Between 2000 and 2020 historians and philologists in the US published a considerable number of books and articles on Muscovite history from 1462 to 1689 . On nearly all major issues there is no consensus, so it is impossible to speak of a "US school" of Russian historiography. This survey, organized thematically, will reference thirty-three books and approximately 350 articles. In each rubric authors are listed alphabetically and their publications chronologically. The survey selectively mentions unstudied topics or topics that require further study and briefly summarizes differences of opinion.

Keywords: Muscovy, 1462, 1649, United States, historiography

Charles J. Halperin - PhD in History, Research Associate, Russian and East European Institute, Indiana University (303 East $8^{\text {th }}$ Street, Apt. 4, Bloomington, IN 47408-3574), e-mail: chalperi@iu.edu

\section{Introduction $^{2}$}

There is no "US School" of Muscovite History. US historians and philologists disagree about virtually all major topics in Muscovite history from 1462 to 1689 , including the periodization of 1462-1689 that defines this survey. One author even called the field "fractious." Some authors refer to the late fifteenth century as "late medieval history." Others refer to the 14621689 period as "pre-modern" rather than "early modern." A growing number now apply to Russia the periodization of European history of "early modern" defined as 1500-1800. This absence of consensus entails that any summary of "American" views on a given issue has to explicate multiple points of view.

Furthermore, $\mathrm{US}^{3}$ scholars on Muscovy have been impressively prolific. While I rigidly excluded publications that appeared before 2000, I included publications whose authors begin before 1462 or end after 1689. I omitted publications in languages other than English but

\footnotetext{
${ }^{1}$ I wish to express my appreciation to Nikolaos Chrissidis and Paul Bushkovich for early bibliographic assistance in preparing this survey and Valerie Kivelson for reading a draft.

2 This survey does not include bibliography which became available to me after September 9, 2020.

${ }^{3}$ All authors cited in this survey are or were employed in the US except for two in Canada, one in Israel, and one in Prague, whom I included because they will not appear in any other national survey, and one affiliated with a German university but who published in English, so it was decided to include her within US historiography.
} 
included works in English regardless of country of publication. The survey mentions fifty-two authors, ${ }^{4}$ some of whom are no longer with us, who published 33 books and, even after excluding articles subsequently incorporated into monographs, approximately 350 articles, far too many to summarize, let alone engage individually, even after I arbitrarily omitted some more. Because some publications treat longer periods, even the entire sixteenth and seventeenth centuries, a chronological arrangement would not have been convenient. I chose a broad thematic organization, although it is not without flaws. Many publications qualify under multiple rubrics, so my categorizations are often debatable. Moreover, such a structure distributes the publications of an author over several rubrics, obscuring the underlying unity of that author's point of view. I have not been consistent in separating source-studies from substantive themes. I neither broke down the material into micro-themes nor included all possible themes. There is no rubric for foreign policy or diplomacy, which has not been the primary focus of any author, ${ }^{5}$ but they are often treated in political narratives or works on military history. It would have been impractical to create a rubric for the growing number of studies of regionalism. Similarly, it was not possible to devote separate space to new areas of research now found in fields other than Russian history such as material culture, ${ }^{6}$ environmental history, or the global turn without disrupting the major rubrics.

For each rubric, as I deemed advisable, I have identified the topics at issue as "Questions," unstudied or understudied themes as "Lacunae," and major differences of opinion as "Summary." Here I sometimes make generic reference to authors not cited under that rubric. Space precludes referring to everyone's views. When I could not personalize the disagreement, I referred to "previous" or "earlier" works. Under each rubric authors appear in alphabetical order and their publications in chronological order. A list of abbreviations appears at the end of this survey.

I cannot draw any synthetic conclusions about the US field of Muscovite history save its productivity and scope.

\footnotetext{
${ }^{4}$ I have not counted co-authors who are not from the US or not specialists in Muscovite history.

5 There is no US equivalent to Jan Hennings of Central European University. I sincerely hope one of the other contributions to this issue will include him.

${ }^{6}$ See Kaiser on tombstones, Kain on Patriarch Nikon, Chrissidis on drinking vessels, and Russell Martin on gifts.
} 


\section{Periodization}

\section{Questions}

Is the Petrine divide no longer a legitimate marker of the "end" of "Muscovite" history? What does utilizing the periodization of "Early Modern" European history, 1500-1800, entail for the concept of Russian “exceptionalism”?

\section{Summary}

Kollmann, Russell Martin and Ostrowski all advocate the European periodization, but they and other historians continue to write studies of "Muscovite history." Thyrêt observes that different spheres of Muscovite history might abide different periodizations.

NANCY ShIEldS Kollmann, The Russian Empire 1450-1801 (Oxford: Oxford University Press, 2017).

Russell E. Martin, "The Petrine Divide and the Periodization of Early Modern Russian History," SR 69 no. 2 (Summer 2010): 410-25.

DONALD OSTROWSKI: "The End of Muscovy: The Case for circa 1800," SR 69 no. 2 (Summer 2010): 426-38.

\section{SOURCE STUDY}

\section{Authenticity and Attribution}

\section{Summary}

Boeck and Ostrowski have revived criticism of the attribution of literary works to Prince Andrei Kubskii and Ivan IV and impugned their authenticity, dissenting from Halperin's conclusions. Keenan disagreed with everyone who attributed Ivan Timofeev's Vremennik to Ivan Timofeev.

Brian J. Boeck: "Eyewitness or False Witness? Two Lives of Metropolitan Filipp of Moscow," JbfGOE 55 (2007): 161-77; “Miscellanea Attributed to Kurbskii. the $17^{\text {th }}$ Century in Russia Was More Creative Than We Like to Admit," Kritika 13 (2012): 955-63; "The Don Interpolation: An Imagined Turning Point in Russian Relations with the Tatar World," in Dubitando, 129-38; "The Improbable Case of the Seventeenth-Century Super Editor: ReConsidering Andrei Lyzlov's History of the Scythians," CASS 49:2/3 (2015): 234-52; "The Lady Vanishes: The Death of Anastasia and Ivan's Regression to Ancestral Evil," RH 47:1-2 (June 2020): 1-10.

EDWARD L. KEENAN, “Who was 'Ivan Timofeev'?” HUS 32-33 no. 1-4 (2011-2014): $415-23$. 
Donald Ostrowski: “'Closed Circles': Edward L. Keenan's Early Textual Work and the Semiotics of Response," Canadian Slavonic Papers 48:3/4 (2006): 247-68; “Attributions to Andrei Kurbskii and Inferential (Bayesian) Probability," CASS 49:2/3 (2015): 211-33.

\section{Book of Degrees (Stepennaia kniga)}

\section{Questions}

Who compiled the text, when, for what audience, what was its message, and why was it unfinished?

\section{Summary}

Except for Keenan, US specialists attribute the Book of Degrees to the metropolitan's chancery during the late 1550 s to early 1560 s. Lenhoff alone ascribes compilation to igumen Levkii of the Moscow Kremlin Chudov Monastery, as opposed to Metropolitan Makarii or Metropolitan Andrei-Afanasii in earlier scholarship, endorses the theory that the text was an Aesopian criticism of Ivan IV's increasingly arbitrary actions, and argues that work stopped because his behavior could no longer be justified. Halperin disagrees.

CHARles J. HALPERIN, "Stepennaia kniga on the Reign of Ivan IV: Omissions from Degree 17," Slavonic and East European Review 89, no. 1 (January. 2011): 56-75.

EDWARD L. KEENAN, “The Stepennaia kniga and the Godunovian Renaissance," in The Book of Royal Degrees, 69-79.

GAIL LENHOFF: "The "Stepennaja kniga" and the Idea of the Book in Medieval Russia," in Germano-Slavistische Beiträge. Festschrift für Peter Rehder zum 65. Geburtstag, ed. MiLOŠ OKUKA AND UlRICH SCHWEIER (Munich: Verlag Otto Sagner, 2004), 449-58; "The Construction of Russian History in the Stepennaia kniga," RES 76 no. 1 (2005): 31-50; "The Economics of a Medieval Literary Project: Direct and Indirect Costs of Producing the Stepennaia kniga," RH 34 no. 1-4 (Spring-Summer-Fall-Winter 2007): 219-37; "The Chudov Monastery and the Stepennaia kniga," FOG 76 (2010): 97-116; "Politics and Form in the Stepennaia kniga," in The Book of Royal Degrees, 154-74; "The Book of Degrees and the Illuminated Chronicle: A Comparative Analysis," RES 87 no. 3-4 (2016): 337-49.

ROBERT RomAnchuK, "Reading History in The Book of Degrees of the Royal Genealogy: Pauline and Platonizing Strategies," in The Book of Royal Degrees, 305-14.

\section{Illustrated Chronicle Compilation (Litsevoi letopisnyi svod)}

Questions 
Who compiled the text, when, for what audience, what was its message, and why was it unfinished? Who wrote the interpolations in the Tsar's Book (Tsarstvennaia kniga)? How do revisions of the text of the Book of Degrees by the compilers of the Illustrated Chronicle Compilation reflect their respective sponsorships or time of compilation? Are the text and miniatures of an event always consistent, and if not, what does that tell us about the editorial management of the project? What is a Russian translation of a Latin prose version of a French chivalric romance almost devoid of Christianity by a thirteenth-century Sicilian judge and poet doing in the Illustrated Chronicle Compilation?

\section{Summary}

Research on the miniatures of the Illustrated Chronicle Compilation is only in its nascent stages and takes various approaches. Kivelson and Kollmann examine the semiotics of gestures, Lenhoff demonstrates inconsistency is drawing Ivan IV post-1547 coronation with a fivepointed crown, not the Cap of Monomakh, and Kleimola argues that the illustrations of Prince Andrei Staritskii's so-called "revolt" show more sympathy for him than the text. It is premature to judge if all these studies will produce a consistent and coherent understanding of the significance of the miniatures. The common assumption of official patronage of the project by the government and/or the church is impugned by Thyrêt's conclusion that the text contradicted Makarii's Great Menology on whether Grand Prince Mikhail of Tver' was a martyr for the faith and Rowland's conclusion that the Illustrated Chronicle Compilation imagined the monarchy more as a corporate than a personal enterprise in a nostalgic evocation of royal consultation in sharp contrast with Ivan IV's lethal treatment of his advisors during the oprichnina.

Brian J. Boeck, "Problems and Possibilities of a 'New' Muscovite Source," Kritika 19, no. 1 (Winter 2018): 9-15.

Paul BushKovitch, "The Trojan War at the Court of Ivan the Terrible," RH 47 no.1-2 (June 2020): 36-48.

VALERIE A. KIVELSON, "Rivers of blood: illustrating violence and virtue in Russia's early modern empire," Journal of the British Academy 3 (2015): 69-105.

AnN M. KLEIMOLA, “"Mistakes Were Made': Text and Image in The Litsevoi Letopisnyi Svod Account of the Staritskii Rebellion,” RES 87 no. 3-4 (2016): 371-84.

NANCY SHIELDS KolLMANN: "Representing Legitimacy in Early Modern Russia," $R R$ 76 no. 1 (January 2017): 7-21; “The Litsevoi svod as Graphic Novel: Narrativity in Iconographic Style," Kritika 19 no. 1 (Winter 2018): 53-82.

ISOLDE THYRÊT: “Saint Stephen of Perm' and the Dual Faith Phenomenon in Muscovite Texts and Images," in Seeing Muscovy Anew, 189-205; "Visualizing the Literary Image of 
Muscovite Royal Wives: Grand Princess Evdokiia in the Skazanie vmale in the Chronicles of Ivan IV's Reign," Kritika 19 no. 1 (Winter 2018): 83-114; "Expressive Gestures: Affect and Hierarchy in the Litsevoi letopisnyi svod," CASS 52 no. 2-3 (November 2018): 234-60.

\section{Foreigner Accounts}

\section{Summary}

Poe defends the reliability of the information in foreigner accounts that Muscovy was a despotism. Adherents of the consensual-collegial interpretation of the nature of the Muscovite state see a "facade of autocracy." In practice most historians evaluate information from foreigner accounts on an individual basis, not by judging the genre of source as a whole.

KeES Boeterbloem, The Fiction and reality of Jan Struys: a seventeenth-century Dutch globetrotter (NY: Palgrave Macmillan, 2008).

Marshall T. PoE: “A People Born to Slavery”. Russia in Early Modern European Ethnography, 1476-1748 (Ithaca: Cornell University Press, 2000); “The Sexual Life of Muscovites: Evidence from the Foreign Accounts," RH 35 no. 3-4 (Fall-Winter 2008): 409-27.

\section{POLITICAL HISTORY}

\section{The Nature of the Muscovite State}

\section{Summary}

Poe, Hellie, and Goldfrank support the theory that Muscovy was a hypertrophic state, although Goldfrank argues that such a state did not require an autocratic ruler and refines Poe's definition of despotism, Hellie conceded that during the Troubles some Muscovites favored a nonautocratic ruler and Poe wrote that Muscovy under Aleksei Mikhailovich was ruled by a coalition of royals, boyars, clerics and military servitors. Kivelson, Ostrowski, Kollmann, and Russell Martin reject the hypertrophic paradigm in favor of the consensual-collegial model. Dunning rejects the theory of absolutism for the fiscal-military state model, but Davies denies that a concept applied to states with totally different political structures has much analytic power. Davies impugns dualistic alternatives as simplistic. Muscovy was under-administered. Halperin concludes that no single model fits the entire Muscovite period.

RoBert O. CRUMMEY, "Seventeenth-century Russia: Theories and Models,” FOG 56 (2000): 113-31.

Chester Dunning And Norman S. SMith, "Moving Beyond Absolutism: Was Early Modern Russia a Fiscal-Military State?” RH 33 no.1 (Spring 2006): 19-44. 
DAVID GolDFRANK: "Aristotle, Bodin, and Montesquieu To the Rescue: Making Sense of the Despotism Issue," FOG 58 (2001): 41-51; “The Deep Origins of Tsar'-Muchitel': A Nagging Problem of Muscovite Political Theory," RH 32 no. 1-4 (Spring-Summer-Fall-Winter 2005): 341-54.

Charles J. HalPerin: "Muscovy as a Hypertrophic State: A Critique," Kritika 3 no. 3 (Summer 2002): 501-7; “The Nature of the Muscovite State During the Reign of Ivan IV: The Tyranny of Concepts," in The State in Early Modern Russia, 77-95.

VAlerIE A. KIVElson, "On Words, Sources, and Historical Method: Which Truth About Muscovy?" Kritika 3 no. 3 (Summer 2003): 487-99.

DONALD OSTROWSKI, "The Façade of Legitimacy: Exchange of Power and Authority in Early Modern Russia," Comparative Studies in Society and History 44 no. 3 (July 2002): 53463.

Marshall Poe, “The Truth About Muscovy,” Kritika 3 no. 3 (Summer 2002): 473-86,

\section{Political Culture}

\section{Summary}

Kivelson formulates a theory of "subject-hood" as a substitute for the concept of "citizenship," implicitly criticizing Hellie and others on Muscovite "servility." Halperin treats political culture as diachronic, not synchronic.

Charles J. Halperin, "Ivan the Terrible and Muscovite Political Culture," in Seeing Muscovy Anew, 49-65.

VALERIE KIVELSON: "Bitter Slavery and Pious Servitude: Muscovite Freedom and its Critics," FOG 58 (2001): 109-19; "Muscovite 'Citizenship': Rights without Freedom,” JMH 74 no. 3 (September 2002): 465-89.

NANCY ShIELDS KollmanN: "Muscovite Political Culture," in A Companion to Russian History, ed. Аввот GLEASON (Chichester, West Sussex, UK: Wiley-Blackwell, 2009), 89-104.

\section{Narratives}

\section{Question}

Can the concept of "modernization" legitimately be applied to Muscovite history? What is the relationship of "state-building" to "empire-building"?

\section{Lacunae}


The reigns of Ivan III, Vasilii III, ${ }^{7}$ Fedor Ivanovich and Mikhail Romanov have not been much investigated.

\section{Summary}

Thyrêt critiqued (before the fact) Kotilaine and Poe's application of the concept of modernization generically to seventeenth-century Muscovy by asserting that from 1400-1700 Muscovy might have been "early modern" in political and economic history but was "medieval" for cultural and religious history, partially supported by Rowland that until 1650 early modern Russian political thought was more early medieval than early modern European thought. Rowland referred to Muscovy's "hypertrophic religion." Against the more common view Keenan concluded that Ivan the Terrible was, if impetuous, not "terrible," and certainly controlled by his "handlers." ${ }^{8}$ Kleimola would not agree with Ostrowski that there were plots to replace Ivan with a Staritskii. Janet Martin disagrees with Ostrowski that Ivan elevated Simeon Bekbulatovich to the Moscow throne to ward off a plot to replace Ivan with the Crimean khan. Bushkovitch debunks Possevino's still widely accepted story of the death of Ivan the Terrible's son Tsarevich Ivan. Janet Martin dissents from Halperin's overview of Ivan IV's reign on gentry social stability. ${ }^{9}$ Dunning denies that Grigorii (Grisha) Otrep'ev was the First False Dmitrii or that there was a social phase to the Time of Troubles, dominant elements of all historiography of the period since Platonov. Kotilaine and Poe assert that until modernization began in the middle of the seventeenth century Muscovy had little in common with contemporary European states, it was stagnant and backward (a word Weickhardt applies to Muscovy), and there is little evidence of systematic or sustained change, despite repeated references to social change (whether state-directed or not) in Muscovy from 1462 on in the works of many authors (including Hellie), who (except Hellie) would also disapprove of the word "backward."

PAul BushKovitch: Peter the Great. The Struggle for Power, 1671-1725 (Cambridge: Cambridge University Press, 2001); "Possevino and the Death of Tsarevich Ivan Ivanovich," CMR 55 no. 1-2 (January-June 2014): 19-34; "Sofia Palaiologina in Life and Legend," CASS 52 no. 2-3 (November 2018): 158-80.

\footnotetext{
${ }^{7}$ On the lack of study of the second half of the fifteenth and the first half of the sixteenth century see VALERIE A. KIVELSON, "Culture and politics, or the curious absence of Muscovite state building in current American historical writing," CMR 46:1-2 (2005): 19-28. DOI: 10.4000/monderusse.8771

${ }^{8}$ See the discussion of the publications of Cornelia Soldat in the survey of German historiography.

${ }^{9}$ So does Maureen Perrie on Ivan and popular culture; see the survey of British historography.
} 
BRIAN DAVIES: "The Razin Rebellion at Tambov and Kozlov, 1670-1671," RH 34 no. 1-4 (Spring-Summer-Fall-Winter 2007): 263-76; "The Road to Pereiaslav: Ukrainian and Muscovite Understandings of Protectorate, 1620-1654," CMR 50 no. 2-3 (April-September 2009): 465-93.

Chester S. L. Dunning: “The Legacy of Russia's First Civil War and the Time of Troubles," FOG 56 (2000): 133-55; Russia's First Civil War: the Time of Troubles and the founding of the Romanov dynasty (University Park: Pennsylvania State University Press, 2001); “Who Was Tsar Dmitrii?" SR 60 no. 4 (Winter 2001): 705-29; “Terror and the Time of Troubles," Kritika 4 no. 3 (Spring 2003): 491-513; "Origins of Russian Royal Pretenderism," in The New Muscovite Cultural History, 143-57.

DAVID GoldFrank, "Paradoxes (?) of Seventeenth-Century Muscovy," FOG 56 (2000): 157-66.

Charles J. HAlPERIN, Ivan the Terrible: Free to Reward and Free to Punish (Pittsburgh: University of Pittsburgh Press, 2019).

RICHARD HELLIE: "Thoughts on the Absence of Elite Resistance in Muscovy," Kritika 1 no. 1 (Winter 2000): 5-20; “Did Russians Ever Hope for Non-Autocratic Rule?" HUS 28 no. 1-4 (2006): 471-82.

Edward L. KeEnAN: "Ivan the Terrible and Book Culture: Fact, Fancy and Fog: Remarks on Early Muscovite Printing," Solanus 18 (2004): 28-50; "How Ivan Became ‘Terrible'," HUS 28 no. 1-4 (2006): 521-42; “The Privy Domain of Ivan Vasil'evich,” in Rude \& Barbarous Kingdom Revisited, 73-88; "Ivan III, Nikolai Karamzin, and the Legend of the 'Casting off of the Tatar Yoke' (1480)," in The New Muscovite Cultural History, 237-51.

VAlerie A. Kivelson, "How Bad Was Ivan the Terrible? The Oprichnik Oath and Satanic Spells in Foreigners' Accounts," in Seeing Muscovy Anew, 67-84.

ANN M. KLEIMOLA: 'I will not listen to my mother': Vladimir Staritskii's Oaths of 1554," in Rusistika Ruslana Skrynnikova, 76-88; "Ivan IV and the Staritskie: Post-Modern Narratives from a Pre-Modern State," in The Book of Royal Degrees, 231-47. "The Road to Beloozero: Ivan IV's Reconciliation with the 'Devil in a Skirt'," RH 42 no.1 (February 2015): 64-81; “' $\mathrm{S}$ ' is 'Seriously?' The Staritskii Plot as 'Disorienting Defense'," $R H 47$ no.1-2 (June 2020): 58-69.

Jarmo Kotilaine And Marshall PoE, "Introduction: Modernization in the Early Modern Context: The Case of Muscovy," in Modernizing Muscovy, 1-7. 
JANET MARTIN, "The Sixteenth-Century Legacy," in Modernizing Muscovy, 8-26; "Pressure Cookers, Safety Valves, and Mass Terror during the Oprichnina," RH 47, no. 1-2 (June 2020) 78-90.

DONALD OSTROWSKI, "The Growth of Muscovy (1462-1533)," in The Cambridge History of Russia, 213-39.

Marshall Poe, "Tsar Aleksei Mikhailovich and the Demise of the Romanov Political Settlement," RR 62 no. 4 (October 2003): 137-64.

\section{Political Institutions, Administration and Law}

Questions

What was the Mongol contribution to Muscovite political institutions and practices? Did Muscovy have a "bureaucracy"?

Summary

Kollmann, Kivelson, and earlier scholars emphasize judicial diligence, Hellie mostly arbitrary injustice, and Weickhardt the brutality and violence of the judicial system. Kivelson adds that sentences could be merciless or humanitarian. Hellie's assertion that the judicial oath declined because of doubts that Russian Orthodox Christianity was the sole source of truth fly in the face of Kaiser's research demonstrating the role of religion in daily life. Brown's conception of a "hypertrophic bureaucracy" in the seventeenth century needs to be reconciled with notions of an unlimited autocrat and/or oligarchic aristocracy.

Peter B. Brown: "With All Deliberate Speed: The Officialdom and Departments of the Seventeenth-Century Muscovite Military Chancellery (Razriad)," RH 28 no. 1-4 (SpringSummer-Fall-Winter 2001): 137-52; "Guarding the Gate-Keepers: Punishing Errant Rank-andFile Officials in Seventeenth-Century Russia," JbfGOE 50 no. 2 (2002): 224-45; "Tsar Aleksei Mikhailovich: Muscovite Military Command Style and Legacy to Russian Military History," in The Military and Society, 119-45; "The Military Chancellery: Aspects of Control during the Thirteen Years' War," RH 29 no. 1 (Spring 2002): 19-42; “Military Planning and High-Level Decision-Making in Seventeenth-Century Russia: The Role of the Military Chancellery (Razriad) and the Boyar Duma," FOG 58 (2002): 79-89; "Neither Fish Nor Fowl: Administrative Legality in Mid- and Late-Seventeenth Century Russia," JbfGOE 50 no. 1 (2002): 1-21; "Bureaucratic Administration in Seventeenth-Century Russia," in Modernizing Muscovy, 57-78; “The Service Land Chancellery Clerks of the Seventeenth Century: Their Regime, Salaries, and Economic Survival," JbfGOE 52 no. 1 (2004): 33-69; "How Muscovy Governed: Seventeenth-Century Russian Central Administration," RH 36 no. 4 (2009): 459- 
529; "Command and Control in the Seventeenth-Century Russian Army," in Warfare in Eastern Europe, 249-314.

PAul BushKOVITCH: "Words and Things: Contemporary Translations of the Russian Institutional Vocabulary (Sixteenth-Seventeenth Centuries," in Seeing Muscovy Anew, 227-43; “The Tsar and the Zemskii sobor: 1613-53," in The State in Early Modern Russia, 133-61.

BRIAN DAVIES, "Local government and administration [1613-1689]," in The Cambridge History of Russia, 464-85.

RICHARD Hellie: "The Law [1462-1613]," in The Cambridge History of Russia, 36086; "The Expanding Role of the State in Russia," in Modernizing Muscovy, 27-53.

VAleRIE A. Kivelson, “'Sovereign, Have Pity on Me!': Anomalies in Muscovite Sentencing," RH 34 no. 1-4 (Spring-Summer-Fall-Winter 2007): 331-39.

NANCY ShIELDS Kollmann: "Judicial Autonomy in the Criminal Law: Beloozero and Arzamas," FOG 63 (2004): 52-68; "Law and society [1613-1649]," in The Cambridge History of Russia, 559-78; Crime and Punishment in Early Modern Russia Cambridge: Cambridge University Press, 2012).

Eve LEVIN: "The Administration of Western Medicine in Seventeenth-Century Russia," in Modernizing Muscovy, 363-89; "The Apterskii Prikaz and the Limits of Western Influence," in The State in Early Modern Russia, 219-47.

DONALD OSTROWSKI, "The Assembly of the Land (Zemskii sobor) as a Representative Institution," in Modernizing Muscovy, 111-36.

MARSHALl POE, "The central government and its institutions [1613-1689]," in The Cambridge History of Russia, 434-63.

GeORge WeickHARDt: “The Canon Law of Rus' and Muscovy, 1100-1551,” RH 28 no. 1-4 (Spring-Summer-Fall-Winter 2001): 411-46; "Modernization of Law in SeventeenthCentury Russia," in Modernizing Muscovy, 76-82; "Early Russian Law and Byzantine Law," RH 32 no.1-4 (Spring-Summer-Fall-Winter 2005): 1-22; "Muscovite Judicial Duels as Legal Fiction," Kritika 7 no. 4 (Fall 2006): 714-32; “The Composite Law Code of 1606," RH 33 no. 1 (Spring 2006): 1-18; "Probable Western Origin of Muscovite Criminal Procedure," RR 66 no. 1 (January 2007): 55-72; "Late Muscovite Criminal Law: The Newly Promulgated Articles of 1669," RH 34 no. 1-4 (Spring-Summer-Fall-Winter 2007): 383-99; "Registering Land Titles in Muscovy," in Rude \& Barbarous Kingdom Revisited, 441-57; "The Law and the Role of Contracts in the Muscovite Tsardom," RH 36 no. 4 (2009): 530-43; "Muscovite Law on Monasteries," RH 39 no. 1-2 (2012): 13-41; "Canon Law Prohibitions on Marriage to Kin in Muscovy," CASS 50 no. 2 (January 2016): 123-41. 


\section{Ideology}

Lacunae

Who dictated the content of non-textual Muscovite ideology requires further study.

\section{Summary}

Bushkovitch uniquely interprets the message of the Moscow Kremlin's architecture as religious, exalting God, not the ruler. Rowland denies Keenan's theory of two cultures because of ecclesiastical cultural influence on the secular court. The atypical American consensus in minimizing the influence of Third Rome ideology on Muscovy contrasts with historiography in other countries.

Paul Bushkovitch, "The Moscow Kremlin and its History," in Britannia and Muscovy. English Silver at the Court of the Tsars, ed. Olga DMitRIEVA AND NATALyA ABRAmOVA (New Haven: Yale University Press, 2006), 218-27.

MichAel S. FLIER: "Till the End of Time: The Apocalypse in Russian Historical Experience Before 1500," in Orthodox Russia, 127-57; "Political ideas and rituals," in The Cambridge History of Russia, 387-408; "Seeing Is Believing: The Semiotics of Dynasty and Destiny in Muscovite Rus,", in Ceremonial Culture in Pre-Modern Europe, ed. NicHOLAs How (Notre Dame: University of Notre Dame Press, 2007), 63-88; “Golden Hall Iconography and the Makarian Initiative," in The New Muscovite Cultural History, 63-75; "Envisioning the Ruler in Medieval Rus': The Iconography of Intercession and Architecture," in Dubitando, 181-91; “Transporting Jerusalem: The Epiphany Ritual in Early St. Petersburg," in Rites of Place. Public Commemoration in Russia and Eastern Europe, ed. JULIE BUCKLER AND EMILY D. JOHNSON (Evanston: Northwestern University Press, 2013), 15-33; "Muscovite Ritual in the Context of Jerusalem Old and New," CASS 49 no. 2-3 (January 2015): 143-59; "Branching Out: The Roots of Muscovite Dynastic Representation," in The State in Early Modern Russia, 5975.

AnN M. KLEIMOLA, “The Icon of the Kazan' Mother of God: The Muscovite Origins of a Russian Palladium," in Gosudarstvo i natsiia v Rossii i Tsentral'no-vostochnoi Evropy, ed. GYUla SzVÁK (Budapest: Russica Pannonica, 2009), 102-20.

Marshall Poe, "Moscow, the Third Rome: the Origin and Transformation of a "Pivotal Moment"," JbfGOE 49 no. 3 (2001): 412-29,

Donald Ostrowski: "Ironies of the Tale of the White Cowl," Palaeoslavica 10 (2002): 1-28; ““"Moscow the Third Rome' as Historical Ghost,” in Byzantium: Faith and Power (12611557): Perspectives on Later Byzantine Art and Culture, ed. SARAH BROOKS (New Haven: Yale 
University Press, 2006), 170-79; "Images of the White Cowl," in The New Muscovite Cultural History, 271-84.

DANIEL Rowland: “Two Cultures, One Throne Room. Secular Courtiers and Orthodox Culture in the Golden Hall of the Moscow Kremlin," in Orthodox Russia, 33-58; “Architecture, Image and Ritual in the Throne Room of Muscovy, 1550-1650: A Preliminary Survey," in Rude and Barbarous Kingdom Revisited, 53-71; “Advice, Advisors, and Courtiers: Decision Making and Advice in the Royal Book of the Illustrated Chronicle Compilation," in Seeing Muscovy Anew, 159-71.

\section{Russia as an Empire}

Questions

Kollmann follows Jane Burbank and Frederick Cooper in defining "empire" as the politics of difference, but there are other definitions. Must an empire think of itself as an empire? Must an empire have colonies or think it had colonies? Did the Muscovite government conceive of Muscovy as the heir of the Juchidulus / Mongol Empire?

\section{Summary}

Kollmann and Romaniello portray a Russian empire pragmatic in practice, but Khodarkovsky attributes ideological motivation to its policies.

PAul BushKovitch: "What is Russia? Russian National Identity and the State, 15001917," in Culture, Nation and Identity. The Ukrainian-Russian Encounter (1600-1945), ed. Andreas Kappeler, ZenOn E. KoHUt, Frank Sysyn ANd Mark von Hagen (Edmonton: Canadian Institute of Ukrainian Studies Press, 2003), 144-61; "Russia," in The Imperial Moment, ed. KIMBERLy KAGAN (Cambridge: Harvard University Press, 2010), 109-40, 220-30.

BASIL DMYTRYSHYN, "Russian Conquest and Subjugation of Northern Asia, 15801650, , in States, Societies, Cultures, 139-55.

Michael Khodarkovsky, Russia's Steppe Frontier. The Making of a Colonial Empire, 1500-1800 (Bloomington: Indiana University Press, 2002).

SERHII PlOKHY, The Origins of the Slavic Nations: Premodern Identities in Russia, Ukraine and Belarus (Cambridge: Cambridge University Press, 2006).

Michael P. Romaniello, Elusive Empire: Kazan and the Creation of Russia, 15521671 (Madison: University of Wisconsin Press, 2012). 


\section{Nationalities}

Questions

How did Muscovy treat its ethnic and religious minorities? Did conversion "erase" ethnic divides? Did loyal service to the dynasty override non-Orthodox, even non-Christian affiliation? Was Muscovy more or less tolerant religiously than its western or eastern neighbors?

MARIA SALOMON AREL, "Cultural Diversity, Imperial Strategies, and the Issue of Faith: Religious Toleration in Early Modern Russia in Comparative Perspective," in The Tapestry of Russian Christianity, 1257-87.

PAul BushKovitch: "Princes Cherkasskii or Circassian Murzas. The Kabardians in the Russian boyar elite 1560-1700," CMR 45 no. 1-2 (January -June 2004): 9-29; “Orthodoxy and Islam in Russia 988-1725,” FOG 76 (2010): 117-43.

BRIAN DAVIES, “The Prisoner's Tale: Russian Captivity Narratives and Changing Muscovite Perception of the Ottoman-Tatar Dar-al-Islam," in Eurasian Slavery, Ransom and Abolition in World History, 1550-1860, ed. Christoph WiTZENRATH (Farnham, Surrey: Ashgate, 2015), 279-94.

MichAel KHODARKOVSKY: "The non-Christian peoples on the Muscovite frontiers [1462-1613]," in The Cambridge History of Russia, 317-37; "Non-Russian subjects [16131689]," in The Cambridge History of Russia, 520-48.

JANET MARTIN: "Multiethnicity in Muscovy: A Consideration of Christian and Muslim Tatars in the 1550s-1580s," Journal of Early Modern History 5 (2001): 1-23; "Tatars in the Muscovite Army During the Livonian War," in The Military and Society, 365-87; "Religious Ideology and Chronicle Depictions of Muslims in $16^{\text {th }}$-Century Muscovy," in The New Muscovite Cultural History, 285-99; "Tatar Pomeshchiki in Muscovy (1560s-70s)," in Mesto Rossii v Evrazii, 114-20; "The Mongol Elite in Muscovy, Rhetoric and Reality: the Portrayal of Tsar Shah Ali in the Book of Degrees of the Royal Genealogy," in The Book of Royal Degrees, 217-29;

"Simeon Bekbulatovich and Steppe Politics: Some Thoughts on Donald Ostrowski's Interpretation of the Tsar's Remarkable Career,” RH 39 no. 3 (2012): 331-38.

DONALD OSTROWSKI: "The Extraordinary Career of Tsarevich Kudai Kul/Peter in the Context of Relations between Muscovy and Kazan'," in States, Societies, Cultures, 697-719; “Simeon Bekbulatovich's Remarkable Career as Tatar Khan, Grand Prince of All Rus', and Monastic Elder," RH 39 no. 3 (2012): 269-99, 339-45. 
DANIEL C. WAUGH, "Networking in the Russian North: The Karino Tatars," RH 45 no. 1 (May 2018): 1-18.

\section{Intellectual History}

\section{Questions}

How did Muscovite political thought differ from West European? What were the limits of political toleration of dissident ideas? Did the absence of secular political theory inhibit Muscovite political actors?

\section{Lacunae}

Goldfrank has not attempted to project his concept of the "republic of sacred letters" into the seventeenth century.

DAVID GOLDFRANK: “Essential Glue: Muscovy's Republic of Sacred Letters, Mid-XIV to Mid-XVI c.," FOG 72 (2010): 335-59; ““Round Up the Usuals” and a Few Others: Glimpses into the Knowledge, Role and Use of Church Fathers in Rus' and Russian Monasticism, Late $11^{\text {th }}$ to Early $16^{\text {th }}$ Centuries," in The Tapestry of Russian Christianity, 71-118.

Daniel Rowland, "Muscovy," in European Political Thought 1450-1700. Religion, Law and Philosophy, ed. Howell A Lloyd, Glenn Burgess, ANd Simon Hodson (New Haven: Yale University Press, 2007), 267-97.

\section{Social History}

\section{Questions}

Did the state dominate society? Did corporate estates exist? Were conditional land-grants hereditary? How did the elite change in the second half of the seventeenth century? How did religion impact daily life? How did witchcraft differ from elsewhere? Did Muscovy enter the "civilizing" process? What role did gender play in society? How important was the nuclear family versus the clan?

\section{Lacunae}

There are no new studies of the peasants/serfs or slaves, perhaps in deference to Hellie's earlier monographs, which he summarized. Peasants show up in studies listed under various rubrics. How do we conceptualize Muscovite society before it supposedly became pro forma a caste society with the institution of serfdom? Did elements of individualism develop in society in tandem with communal identities? 


\section{Summary}

Janet Martin disputes earlier US historiography on the heritability of conditional landed estates. Despite Hellie's emphasis on gentry lifetime service, Janet Martin observes that frequently gentry-men were released from service for reasons of health or just age. No specialist has followed up on Hellie's theories of the neurological pathology of the Russian peasantry. Historians contradict themselves on the degree of de facto social mobility. In general advocates of the hypertrophic state paradigm assert that the state dominated society, while opponents of that paradigm find autonomous spheres of activity in various social classes. Implicitly the conclusion of Chrissidis that there was no distinction between the culture of the church / monastery and that of the court /bureaucracy impugns Keenan's model of the Two Cultures in the sixteenth century (Keenan does not project the Two Cultures into the seventeenth century). Chrissidis points out the lack of any medicinal discourse on tobacco in Muscovy, but Levin asserts that it was used medicinally anyway, which is not a contradiction because the foreign doctors of the Pharmacy Chancellery were familiar with that discourse before they arrived in Muscovy.

NIKOlaOS CHRISSIDIS, "Whoever does not drink to the end, he wishes evil: Ritual Drinking and Politics in Early Modern Russia," in The New Muscovite Cultural History, 20724; "Sex, Drink and Drugs: Tobacco in Seventeenth-Century Muscovy," in Tobacco in Russian History, 26-43.

RICHARD HeLliE: "The Russian Smokey Hut and its Probable Health Consequences," RH 28 no. 1-4 (Spring-Summer-Fall-Winter 2001): 171-84; "Interpreting Violence in Late Muscovy from the Perspective of Modern Neuroscience," in States, Societies, Cultures, 295315; "Reflections on Muscovite Society in the Second Half of the Fifteenth Century," in PreModern Russia and Its World. Essays in Honor of Thomas S. Noonan, ed. KATHRYN L. REYERSON, TheOfANis G. STAVROU, AND JAMES D. TRACy (Wiesbaden: Harrassowitz Verlag, 2006), 155-60; "Russian Peasant Nutrition 1650 and 1850 and Its Probable Consequences," in Vremena i sud'by. Sb. st. v chest' 75-letiia Viktora Moiseevicha Paneiakha (St. Petersburg: Evreiskii dom, 2006), 143-71; “The Peasantry [1462-1613]," in The Cambridge History of Russia, 286-97.

DANIEL H. KAISER: "Default and Deception in Muscovite Weddings," in Ot Drevnei Rusi k Rossii novogo vremeni. Sbornik statei. K 70-letiiu Anny Leonidovny Khoroshkevicha (Moscow: Nauka, 2003), 432-37; “Quotidian Orthodoxy. Domestic Life in Early Modern Russia," in Orthodox Russia, 179-92; “Testamentary Charity in Early Modern Russia: Trends and Motivations," JMH 76 no. 1 (March 2004): 1-28; "Discovering Individualism Among the 
Deceased: Gravestones in Early Modern Russia," in Modernizing Muscovy, 433-59; "The Practical Importance of Genealogy in Early Modern Russia," RH 33 no. 2-4 (Summer-FallWinter 2006): 455-66; "Church Control over Marriage in Seventeenth-Century Muscovy," $R R$ 65 no. 4 (October 2006): 567-85; "Law, Gender and Kin in Seventeenth-Century Muscovy," RH 34 no. 1-4 (Spring-Summer-Fall-Winter 2007): 315-30; "Miasoed Konstantin Semenovich Vislyi: Oprichnina Victim ... and Beloozero zemliak," in Rusistika Ruslana Skrynnikova, 10917.

VAlERIE A. KIVELSON: Cartographies of Tsardom: the land and its meaning in seventeenth-century Russia (Ithaca: Cornell University Press, 2006); Desperate Magic: the moral economy of witchcraft in seventeenth-century Russia (Ithaca: Cornell University Press, 2013); “'So They Will Love Me and Pine for Me': Intimacy and Distance in Muscovite Magic," in Emotions in the History of Witchcraft, ed. LAURA KOUNINE AND MICHAEL OSTLING (London: Palgrave Macmillan, 2017), 117-36.

VALERIE KiVELSON AND Jonathan ShaHEen, "Prosaic Witchcraft and Semiotic Totalitarianism: Muscovite Magic Reconsidered," SR 70 no.1 (Spring 2011): 23-44.

Nancy Shields KollmanN: "What's Love Got to Do with It? Changing Models of Masculinity in Muscovite and Petrine Russia," in Russian Masculinity in History and Culture, ed. Barbara Evans Clements, RebecCa Friedman And Dan Healy (NY: Palgrave, 2002), 15-32; "Society, Identity and Modernity in Seventeenth-Century Russia," in Modernizing Muscovy, 406-20. "Gender and the Problem of Muscovite Peculiarities," in Moskovskaia Rus', 34-41; "Self, Society and Gender in Early Modern Russia and Eastern Europe," in A Companion to Gender History, ed. THERESA A. MEAD (Oxford: Blackwell, 2004), 358-70; "Beginning a Civilizing Process: Handbooks of Morals and Behavior in Early Modern Russia," in Everyday Life in Russian History, 329-43.

RACHEL KorOLOFF: "The Patriarch and the Apothecary: Planting Gardens and Making Miro in the Seventeenth Century," in Sound and Sent in the Garden ed. D. Fairchild Ruggles (Washington, DC: Dumbarton Oaks Research Library and Collection, 2017), 53-69; "Juniper. From Medicine to Poison and Back Again in Seventeenth-Century Muscovy," Kritika 19:4 (Fall, 2018): 697-716; “Travniki, Travniki and Travniki: Herbals, Herbalists, and Herbaria in Seventeenth-Century and Eighteenth-Century Russia," Vivliofika 6 (2018): 8-76

Eve Levin: "Identifying Diseases in Pre-Modern Russia," RH 35 no. 3-4 (Fall-Winter 2008): 321-33; "Tobacco and Health in Early Modern Russia," in Tobacco in Russian History, 44-60; "Healers and Witches in Early Modern Russia," in Saluting Aaron Gurevich: Essays in History, Literature and Other Subjects, ed. YelEnA MAZOUR-MATUSEVICH AND ALEXANDRA 
S. KorRos (Leiden: Koninklijke Brill NV, 2010), 105-33; "Prison or Asylum: The Involuntary Commitment of the Insane to Monasteries in Early Modern Russia," in Seeing Muscovy Anew, 245-62.

JANET MARTIN: "Peculiarities of the Pomest'e System: A Comparison of Novgorod and Tver' in the Mid-Sixteenth Century," in Moskovskaia Rus', 76-87; “Two Pomeshchiki From the Novgorod Lands: Their Fates and Fortunes during the Livonian War," RH 34 no. 1-4 (Spring-Summer-Fall-Winter 2007): 239-53; “The Heritability of Pomest'e Estates in $16^{\text {th }}$ Century Muscovy: An Analysis of the Experience of Four Families," in Everyday Life in Russian History, 231-46; "From Fathers to Sons? Property and Inheritance Rights of Pomeshchiki in $16^{\text {th }}$-century Muscovy," in Rusistika Ruslana Skrynnikova, 68-75; "Netstvo and the Conditionality of Pomest'e Land Tenure," in Dubitando, 461-73; "The Bachmanov Brothers' Petitions: A Window into the Pomest'e System in the 1570s," RH 44 no. 4 (December 2017): 534-46; “The Pomest'e System of $16^{\text {th }}$-Century From the Perspective of a Military Service Family,” Drevniaia Rus' 2019 no. 1 (75) (March 2019): 72-75.

RUSSELl E. MARTIN: "Gifts for Kith and Kin: Gift Exchanges and Social Integration in Muscovite Royal Weddings," in Rude \& Barbarous Kingdom Revisited, 89-108; "Praying for Health, Heirs, Victory over Enemies, and Prosperity: Projecting the Interests of Dynasty through Gifts at Muscovite Royal Weddings," in Everyday Life in Russian History, 23-42; A Bride for the Tsar: Bride-Shows and Marriage Politics in Early Modern Russia (DeKalb: Northern Illinois University Press, 2012); "Prayers for the Dead in Muscovy; Kinship, Awareness and Orthodox Belief in the Commemorations of Muscovite Royalty," in The Tapestry of Russian Christianity, 189-228; “"To Serve Without Regard to Place': Precedence and Royal In-Laws at the Weddings of Russia's Rulers, 1525-1671," in Seeing Muscovy Anew, 85-103; "Familial Order, Dynasty and Succession in Early Modern Russia: Toward a Gendered History of the Muscovite Dynasty," in The State in Early Modern Russia, 29-58.

GEORG Michels, "Rituals of Violence: Retaliatory Acts by Russian and Hungarian Rebels," RH 35 no. 3-4 (Fall-Winter 2008): 383-94.

DonAlD Ostrowski, "Early Pomest'e Grants as a Historical Source,” Oxford Slavonic Papers 32 (2000): 36-63.

Marshall PoE, "Absolutism and the New Men of Seventeenth-Century Russia," in Modernizing Muscovy, 93-110.

Matthew P. Romaniello, “Muscovy's Extraordinary Ban on Tobacco,” in Tobacco in Russian History, 9-25. 
JENNIFER SPOCK: "Community Building and Social Identity: Donations to the Solovki Monastery 1460-1645," JbfGOE 55 no. 4 (2007): 534-65; "Giving Voice to the Voiceless: Expressions of Non-Elite Identity and Perspectives in Pre-Petrine Russia," in Religion and Identity in Russia, 25-41.

\section{History of Women}

\section{Questions}

Were women's rights increasing or decreasing in Muscovy, or both? Did royal women play a private role in politics despite the absence of a public role? Why did the government change its position on whether widows of conditional-land grant holders should receive a widow's portion of the land or live with relatives? Why did the state begin to intervene in a sphere of private life previously left to the Russian Orthodox Church to regulate? Was women's spirituality different than men's?

\section{Lacunae}

Kollmann noted that women's role in the economy has not been adequately studied. Eve Levin's study of sexuality has not inspired further research.

\section{Discussion}

Kollmann consistently emphasizes the limited range of issues that government thought it necessary to deal with" but Kaiser and Janet Martin note gradual state intervention into family issues related to women.

DANIEL H. KAISER: "Invading the 'Private': Spousal Violence and the State in Early Modern Russia," FOG 58 (2001): 135-42; 'He Said, She Said': Sexual Assault and Gender Discourse in Early Modern Russia," Kritika 3 no. 2 (Spring 2002): 197-216; “"Whose Wife Will She Be at the Resurrection?' Marriage and Remarriage in Early Modern Russia," SR 62 no. 2 (Summer 2003): 302-23; "Property among Elite Women in17th-century Muscovy," in Rude \& Barbarous Kingdom Revisited, 427-40; "Pomest'e prozhitki: Muscovite Patriarchy on the Ground," RH 42 no. 1 (February 2015): 82-96.

VALERIE A. KIVELSON, “Sexuality and Gender in Early Modern Russian Orthodoxy: Sin and Virtue in Cultural Context," in Letters from Heaven, 100-25.

Ann M. Kleimola: “A Woman's Gift: the Patronage of Commemoration in the Russian North,” FOG 58 (2001): 151-61; “A Refuge for Women on Muscovy’s Southern Frontier,” in Rol' gosudarstva $v$ istoricheskom razvitii Rossii / Role of the State in the Historical Development of Russia, ed. GyUla SzvÁK (Budapest: Russica Pannonica, 2011), 91-99. 
Janet Martin: “The Pomest'e System as a Means of Support for Women in SixteenthCentury Muscovy," in Novye napravleniia, 61-73; "Women, the Pomest'e System, and Muscovite State Authority in the First Half of the Sixteenth Century," in Seeing Muscovy Anew, 209-25.

Marshall Poe, "The Public Face of Private Life: the Family-Presentation Ritual in Muscovite Russia," in Everyday Life in Russian History, 5-21.

CARol B. Stevens: "Women and the Russian Military, 1650-1730: A Preliminary Survey," in Dubitando, 473-90; "Women and War in Early Modern Russia (Seventeenth to Eighteenth Centuries)," in A Companion to Women's Military History, ed. BARTON C. HACKER AND MARGARET VINING (Leiden: Brill, 2012), 387-408.

ISOLDE THYRÊT: Between God and Tsar. Religious Symbolism and the Royal Women of Muscovite Russia (DeKalb: Northern Illinois University Press, 2001); "Women and the Orthodox Faith in Muscovite Russia. Spiritual Experience and Practice," in Orthodox Russia, 159-85; “The Royal Women of Ivan IV's Family and the Meaning of Forced Tonsure," in Servants of the Dynasty: Women in World History ed. AnNE WALTHALl (Berkeley: University of California Press, 2008), 159-71; "Muscovite Women and the Politics of the Holy: Gender and Canonization," RH 35 no. 3-4 (Fall Winter 2008): 447-61; “The Queen of Heaven and the Pious Maiden Ruler: Mariological Images in the Iconographic Program of Sofiia Alekseevna's Prayer Room,” HUS 28 no. 1-4 (2008): 627-37; ““The Tale of the Death of Vasilii Ivanovich and the Evolution of the Muscovite Tsaritsa's Role in $16^{\text {th }}$-Century Russia," in Dubitando, 20924.

\section{Economic History}

Questions

How did conditional-land holders in the sixteenth century adapt to changing economic conditions? Was the seventeenth-century Muscovite government mercantilist? Were Muscovite merchants backward, weak, and dependent upon the state? Did Muscovy develop a bourgeoisie? What was the role of domestic and international trade in Muscovy? How monetary was the economy?

\section{Lacunae}

In general economic history has received less attention than other themes. No US historian has updated Petrikeev's 1967 or Shvachenko's 1990 study of large patrimonial estates in the seventeenth century. Artisans and all "suburban people" (posadskie liudi) have escaped serious attention. 


\section{Discussion}

Monahan and Kotilaine follow Bushkovitch's earlier study in rejecting Baron's early depiction of the merchants as failing to live up to a non-existent Weberian ideal before Baron's views evolved.

MARIa SAlomon AREL, English Trade and Adventure to Russia in the Early Modern Era: The Muscovy Company, 1604-1649 (Lanham: Lexington Books, 2019).

RICHARD HELLIE: "Early Modern Russian Estate Management and Economic Development," in European Aristocracies and Colonial Elites. Patrimonial Management Strategies and Economic Development, $15^{\text {th }}-18^{\text {th }}$ Centuries, ed. PAUL JANSSENS AND BARTOLOME Yun-CASALliLA (Aldershot: Ashgate Publishing Company, 2005), 179-95; "The economy, trade and serfdom [1613-1689]," in The Cambridge History of Russia, 539-58.

Jarmo Kotilaine, "Mercantilism in Pre-Petrine Russia," in Modernizing Muscovy, 137-66; Russia's foreign trade and economic expansion in the seventeenth century (Leiden: Brill, 2004).

Janet Martin, "Economic Effectiveness of the Muscovite Pomest'e System: An Examination of Estate Incomes and Military Expenses in the Mid-16th Century," in Warfare in Eastern Europe, 19-34.

ERIKA MONAHAN, The merchants of Siberia: trade in early modern Russia (Ithaca: Cornell University Press, 2016).

\section{Religion and Ecclesiastical History}

Questions

Were the Judaizers Judaizers? How did Muscovite monasteries differ in their social profiles, welfare activities, interpretation of monastic equality, organization, life-style, and links to the elite? How did the social affiliation of donors to monasteries affect the type of donations they made ? Was the heightened role of confession in seventeenth-century Muscovy a product of Ukrainian influence? Can Avvakum's life and writings be understood within the context of the concepts of Holy Foolishness and Wisdom theology? How prevalent were regional religious identifies?

\section{Summary}

In general US scholars have turned increasingly to studies of Muscovites spirituality and religious practice. Bushkovitch, Goldfrank and Miller contest Ostrowski's earlier argument that there were no monastic factions in mid sixteenth-century Muscovy. Miller disagrees with Bushkovitch on the role of the ruler in selecting heads of the Russian Orthodox Church. It is 
unclear if Miller's portrayal of Makarii as a conniving politician who rigged his own eventual elevation to the metropolitanate is compatible with Flier's depiction of Makarii as the disinterested master political and ecclesiastical impresario of the first fifteen years of Ivan's reign. Goldfrank dissents from Dykstra's evaluation of the influence of the Iosifov Monastery before 1587. Kaiser, Crummey and others dispute Michels's argument that neither the clergy nor the laity during the Schism were motivated by religion. According to Kaiser the Church had already imposed its rules forbidding consanguineous marriages before according to Michels the laity turned to the "schism" to repulse outside control of their lives. Kleimola evaluates Archbishop Afanasii differently than Michels. Kain's image of Patriarch Nikon differs from that of Michels. Kain also concludes that seventeenth-century Old Believer clerical works do represent the views of the illiterate Old Believer masses. Thyrêt and Levin see canonization as an amorphous bottom-up process, not controlled centrally, in which composing a vita was less important than Bushkovitch proposed. There is no consensus on the balance of religious and secular (mercenary and institutional) motives in the operation of monasteries, but in one case Thyrêt follows Gruber's "business, corporate enterprise" model of Muscovite monasteries, compatible with Michels's judgment of virtually the entire seventeenth-century Russian ecclesiastical establishment. On the whole though Thyrêt rejects Gruber's attribution of a "profit mentality" to monasteries, including on commemoration prayers.

Paul BushKovitch, "The Selection and Deposition of the Metropolitan and Patriarch of the Orthodox Church in Russia, 1448-1619," in Etre catholique - être orthodoxe - être protestant. Confessions et identités culturelles en Europe médiévale et moderne, ed. MAREK DERWICH AND MiKHAIL V. DMITRIEV (Wrocław: LARHCOR, 2003), 123-150.

TOM E. DYKSTRA, Russian Monastic Culture. "Josephism” and the Iosifo-Volokolamsk Monastery, 1479-1607 (Munich, Otto Sagner Verlag, 2006).

Robert O. CRUMMEY: "Ecclesiastical Elites and Popular Belief and Practice in Seventeenth-Century Russia," in Religion and the Early Modern State. Views from China, Russia and the West, ed. JAMES D. TRACY AND MARGUERITE RAGNOW (Cambridge: Cambridge University Press, 2004), 52-79; "The Orthodox Church and the schism," The Cambridge History of Russia, 618-39.

DaVID M. GoldFRAnK: tr., The Monastic Rule of Iosif Volotskii, rev. ed. (Kalamazoo: Cistercian Publications, 2000); “The Literary Nil Sorskii," HUS 28 no. 1-4 (2006) 429-39; "Sisterhood Just Might Be Powerful: The Testament and Rule of Elena Devochka," RH 34 no. 1-4 (Spring-Summer-Fall-Winter 2007): 189-205; "Recentering Nil Sorskii: the Evidence from the Sources," RR 66 no. 3 (July 2007): 359-76; tr. Nil Sorsky, The Authentic Writings 
(Kalamazoo: Cistercian Publications, 2008); "Nil Sorskii and Prosvetitel', “ in Rude \& Barbarous Kingdom Revisited, 215-29; "Nil Sorskii's Following among the IosifovVolokolamsk Elders," in The New Muscovite Cultural History, 207-22; "Iosif, Nil, or Both: Iosiflianstvo and Hesychasm in the Stepennaia kniga," in The Book of Royal Degrees, 315-32; "Nil's and Iosif's Rhetoric of Starchestvo," RH 39 no. 1-2 (2012): 42-76; “Adversus Haereticos Novgorodensos: Iosif Volotskii's Rhetorical Syllogisms," in Dubitando, 245-74; "The Anatomy of the Key Codices and the Ontogeny of Prosvetitel'," CASS 49 no. 2-3 (January 2015) 160-73; “Litigious, Pedagogical, Redemptive, Lethal: Iosif Volotskii's Calculated Insults," RR 75 no. 1 (January 2016): 86-106; “Iosif Volotskii's Disputational Technique (Ars Disputandi)," in Iosif Volotskii and Eastern Christianity, 153-82; "The Evergetian Motif in Russian Monastic Reform," in Thresholds into the Orthodox Commonwealth. Essays in Honor of Theofanis G. Stavrou, ed. LuCIEN J. FrARY (Bloomington: Slavica, 2017), 71-89; "The 'Judaic-Reasoning Novgorod Heretics' and Some Echoes of Spain in Late Medieval Russia,' RH 44:4 (2017): 547-69; "By Dishonor in a Bind-Imperatives and Paradoxes in the Writings of Iosif Volotskii," in Seeing Muscovy Anew, 107-22.

ISAIAH GRUBER, Orthodox Russia in Crisis: church and nation in the Time of Troubles (DeKalb: Northern Illinois University Press, 2012).

PRISCILla HunT: “Avvakum's Fifth Petition to the Tsar and the Ritual Process," Slavic and East European Journal 46 no. 3 (Fall 2002): 483-510; "The Foolishness in the Life of the Archpriest Avvakum and the Problems of Innovation," RH 35 no. 3-4 (Fall-Winter 2008): 275308; "The Theology in Avvakum's Life and His Polemic with the Nikonians," in The New Muscovite Cultural History, 125-40; "Holy Foolishness as a Key to Russian Culture," in Holy Foolishness in Russia, 1-14; "The Fool and the King: The Vita of Andrew of Constantinople and Russian Urban Holy Foolishness," in Holy Foolishness in Russia, 149-224; "Mysteries in Muscovite Political Theology: Rabbits, Snakes, and Lions in the Kremlin Golden Palace Throne Room Frescoes," RH 44 no. 2-3 (June 2017): 181-208.

KEVIN KAIN: “A Comparative, Semiological and Iconographical Analysis of Patriarch Nikon Inspired by the 'Life of Kornili',"“ Mir staroobriadchestva, ed. I. V. POZDEVA AND E. V. Stilianskaia (Iaroslav: Remder) 6 (2008): 141-68; "Before New Jerusalem: Patriarch Nikon's Iverskii and Krestnyi Monasteries,” RH 39 no. 1-2 (2012): 173-231; “"New Jerusalem” in Seventeenth-Century Russia: The Image of a New Orthodoxy Holy Land," CMR 58 no. 3 (July-September 2017): 371-94; "Deacon Feodor Ivanov as a Follower of Iosif Volotskii or The Enlightener and 'The Wolf and Predator ... Nikon," in Iosif Volotskii and Eastern Christianity, 214-38. 
From Peasant to Patriarch. Account of the Birth, Uprising, and Life of His Holiness Nikon, Patriarch of Moscow and All Russia ,written by His Cleric Ioann Shusherin, tr. KeVIN KAIN AND KATIA LEVINTOVA (Lanham: Lexington Books, 2007).

DANIEL H. KAISER, "Beyond the Pages of the Stepennaia kniga: Icon Veneration in $16^{\text {th }}$ Century Muscovy," in The Book of Royal Degrees, 287-301.

NADIESZDA KIZENKO, "The Sacrament of Confession as an Encounter with Early Modernity" in The State in Early Modern Russia, 163-89.

AnN M. KLEIMOLA: “The Paradoxes of Kozheozero,” RH 39 no. 1-2 (2012): 232-46; "Networking in Muscovy: Archbishop Afanasii of Kholmogory and his Capital," RH 44 no. 23 (June 2017): 314-29.

Eve LEvin: "From Corpse to Cult in Early Modern Russia," in Orthodox Russia, 81103; "The Christian Sources of the Cult of St. Paraskeva," in Letters from Heaven, 126-45; "Near Death Experiences," in Rude \& Barbarous Kingdom Revisited, 411-25; "Innocent and Demon-Possessed in Early Modern Russia," in Culture and Identity in Eastern Christian History., ed. Russell E. MARTin AND Jennifer Spock with the ASSistance of M. A. JOHNSON (Columbus: Department of Slavic and East European Languages and Literatures, OSU, 2009), 123-61.

GeORG Michels: "The Rise and Fall of Archbishop Stefan: Church Power, Local Society and the Kremlin during the Seventeenth Century," FOG 56 (2000): 203-26; "Opportunists, Idealists and Functionaries: The Men Who Ruled the Russian Church under Nikon (1652-1666)," FOG 58 (2001): 199-206; "Rescuing the Orthodox: The Church Policies of Archbishop Afanasii of Kholmogory, 1682-1702," in Of Religion and Empire. Missions, Conversions and Tolerance in Tsarist Russia, ed. ROBERT P. GERACI AND MICHAEL KHODARKOVSKY (Ithaca: Cornell University Press, 2001), 19-37; "Patriarch Nikon in Exile at the Ferapontov Monastery (1666-76), in In the Realm of Slavic Philology. To Honor the Teaching and Scholarship of Dean S. Worth from his UCLA Students, ed. JOHN DINGLEY AND LEON FERDER (Bloomington: Slavica, 2002), 201-13; "Ruling Without Mercy: SeventeenthCentury Russian Bishops and Their Officials," Kritika 43 no. 3 (Summer 2003): 515-42; “Apocalypse on Lake Onega: The Destruction of an Island Community," Cahiers slaves No. 7 (2004): 95-113; “The Patriarch's Rivals: Local Strongmen and the Limits of Church Reform during the Seventeenth Century," in Modernizing Muscovy, 316-40; "The Monastic Reforms of Archbishop Afanasii of Kholmogory (1682-1702),” FOG 63 (2004): 220-35; “Ivan Neronov: A Priest Who Lost His Mind," in Rude \& Barbarous Kingdom Revisited, 269-85; "Some Observations on the Social History of Old Belief During the Seventeenth Century," in Russia's 
Dissident Old Believers 1650-1950, ed. GEORG B. Michels AND ROBERT L. NichOlS (Minneapolis: University of Minnesota, 2009), 139-65; "Power, Patronage and Repression in the Church Regime of Patriarch Filaret (1619-33)," FOG 76 (2010): 81-96; "From Persecuted Minority to Confessional Church: Some Thoughts on the New Extinction and Ultimate Survival of Old Belief (1650s-1730s)," CASS 49 no. 2-3 (January 2015): 322-37.

DAVID B. MiLleR: “The Orthodox Church [1462-1613]," in The Cambridge History of Russia, 338-59; Saint Sergius of Radonezh, His Trinity Monastery, and the Formation of the Russian Identity (DeKalb: Northern Illinois University Press 2010); "The Politics and Ceremonial of Ioasaf Skrypitsyn's Installation as Metropolitan on February 9, 1539," $R R 70$ no. 2 (April 2011): 234-51.

DONALD OSTROWSKI: "Direction of Borrowing between Vitae: The Life of Iosif of Volokolamsk by Lev Filolog and the Life of Serapion, Archbishop of Novgorod," Palaeoslavica 13 no. 1 (2005): 109-41; "Parallels of Mysticism: The Hesychasm of Nil Sorskii and Sufism," in Nil Sorskii v kul'ture i knizhnosti Drevnei Rusi, ed. A. I. AlEKSEEV, S.A. DAVYDOvA, E. v. Krushitel'NitskAiA, ZH. L. LeVShinA, AND T . P. LËNNGREN (St. Petersburg: Russkaia natsional'naia biblioteka, 2008), 41-52; “The Letter concerning Enmities as a Polemical Source for Monastic Relations of the Mid-Sixteenth Century," RH 39 no. 1-2 (2012): 77-105; "The Moscow Councils of 1449 to 1589 and the Conciliar Period in Russian Orthodox Church History," in The Tapestry of Russian Christianity, 121-55; "Unresolved Evidentiary Issues Concerning Rus' Heretics of the Late $15^{\text {th }} /$ Early $16^{\text {th }}$ Centuries," in Seeing Muscovy Anew, 123-39; “"The Debate with Iosif' (Prenie s Iosifom Volotskim). A Fictive Disputation,” in Iosif Volotskii and Eastern Christianity, 182-211.

T. Allan Smith, The Volokolamskii Paterik. A Window on a Muscovite Monastery (Toronto: Pontifical Institute of Mediaeval Studies, 2008).

JENNIFER SPOCK: "Regarding the Good Order of the Monastery: The Tipik Solovetskago and the Integration of the Spiritual with the Temporal in the Early Seventeenth Century," in Rude \& Barbarous Kingdom Revisited, 251-67; "Administering a Right Life: Secular and Spiritual Guidance at Solovki in the Sixteenth and Seventeenth Centuries," RH 39 no. 1-2 (2012): 148-72; "Monasticism in Russia's Far North in the Pre-Petrine Era: Social, Cultural and Economic Interaction," in Monasticism in Eastern Europe and the Former Soviet Republics, ed. INES ANGELI MurZAKU (London: Routledge, 2016), 285-307; "Northern Russia's Monastic Culture," in The Tapestry of Russian Christianity, 229-59; "Identifying PrePetrine Pilgrims in Monastic Archival Records: Solovki as a Case Study for Categorizing Visitors' Monies," in Religionsgeschichitliche Studien zur ostlichen Europa: Festschrift für 
Ludwig Steindorff zur 65 Geburtstag, ed. MARTINA THOMSEN (Stuttgart: Fanz Steiner Verlag, 2017), 121-32; “The Anchorite and the Cenobium: The 'Life of Nikifor' and its Meaning for Solovki Monastery," CASS 52 no. 2-3 (November 2018): 327-40.

ISOLDE THYRÊT: "The Cult of the True Cross in Muscovy and Its Reception in the Center and the Regions," FOG 63 (2004): 236-58; "Whose Cults are They? the Local and Central Contexts of the Veneration of Saints Arsenii and Mikhail of Tver'," FOG 76 (2010): 413-46; ““"Economic Reconstruction or Corporate Raiding? The Borisoglebskii Monastery in Torzhok and the Ascription of Monasteries in the $17^{\text {th }}$ Century," Kritika 11 no. 3 (Summer 2010): 490511; “'One Town's Saint is Another's Worst Nightmare: Saints' Cults and Regional Identity in Medieval and Early Modern Russia's Upper Volga Region,” in Cuius patrocinio tota guadet regio: saints' cults and the dynamics of regional cohesion, ed. STANISLAVA KuZMOVA, ANA MARINKOVIC, AND TRPIMIR VEDRIS (Zagreb: Bibliothea Hagiotheca, Series Colloquia, III 2014), 35-50; "The Esipov Chronicle and the Creation of the Concept of Siberia as a Special Sacred Space," RH 44 no. 4 (December 2017): 594-607; "Creating a Religious Community in Siberia: The Cultural Politics of Archbishop Nektarii of Tobol'sk," CASS 51 no. 1 (January 2017): 87-104; Saint Making in Early Modern Russia: Religious Tradition and Innovation in the Cult of Nil Stolbenskii (Washington, DC: New Academic Publishers, 2019).

ElizABeth Kritofovich Zelensky, “New Maiden’s Convent: Matrix of Empire,” in Love of Learning and Devotion to God in Orthodox Monasteries, ed. MiROLIUB JoKOviCH, Daniel Collins, M. A. Johnson And PRedrag Matejic (Columbus: Center for Medieval Slavic Studies, OSU, 2006), 198-210.

\section{Iconography}

Questions

How did regional, provincial iconography differ from royal iconography? What are the differences among the preservation, conservation, restoration and reconstruction of icons?

AnN M. KLEIMOLA: "Following the Threads: The Rediscovery and Restoration of Muscovite Iconographic Needlework," in Novye napravleniia, 33-51; "The Icon as an Open Book: Reflections on North Russian Culture," RH 33 no. 2-4 (Summer-Fall-Winter 2006): 40727; "Regulating Icon Painters in the Era of the Ulozhenie: Evidence from the Russian North," RH 3 no. 1-4 (Spring-Summer-Fall-Winter 2007): 341-63; "Icon-Painting in the Russian North: Evidence from the Antonievo-Siiskii Monastery," in Rude \& Barbarous Kingdom Revisited, 327-39; “A Century of Reappraisals: The Severnye pis'ma and the 'Uncovering' of a Vologda 
School of Ikon Painting," in Regional'nye shkoly russkoi istoriografii / Regional Schools of Russian Historiography, ed. GYULA SzVÁK (Budapest: Russica Pannonica, 2007), 82-102.

DANIEL C. WAugh, "Religion and Regional Identities: The Case of Viatka and the Miracle-Working Icon of St. Nicholas Velikoretskii,” FOG 63 (2004): 259-78.

\section{Military History}

\section{Questions}

Was the sixteenth-century Muscovite army inferior to Western armies? What was the pace of military reform ("Westernization") in the seventeenth century? When and how did newformation infantry replace gentry archer-cavalry as the foundation of Muscovy's armed forces?

\section{Summary}

Davies attributes a longer-lasting military role to gentry cavalry in the seventeenth century than Hellie. Davies also rates the Muscovite placement of infantry behind wagenlagers as the major difference between eastern and western infantry tactics, not the contrast between musketeers (strel'tsy) and the new formation infantry regiments. Finally, Davies presents a more positive evaluation of Golitsyn's campaigns against Crimea than that found in most works. Stephens questions the contrast between warfare on the western and eastern/southern fronts commonly found in the literature. Bushkovitch questions the impact of the new-style infantry regiments, the object of much attention by other historians, before Peter the Great.

Paul BushKOVITCH, "The Romanov Transformation 1613-1725," in The Military History of Tsarist Russia, 31-45.

BRIAN DAVIES: "The Foundation of Muscovite Military Power, 1453-1613," in The Military History of Tsarist Russia, 11-30; “The Second Chigirin Campaign (1678): Late Muscovite Military Power," in The Military and Society, 97-118; State Power and Community in Early Modern Russia: The Case of Kozlov, 1635-1649 (Houndmills, Basingstoke, Hampshire: Palgrave Macmillan, 2004); "Muscovy at war and peace [1613-1689]," in The Cambridge History of Russia, 86-519; Warfare, State and Society on the Black Sea Steppe, 1500-1700 (London: Routledge Taylor and Francis, 2007); “The Polotsk Campaign of Ivan IV and Stefan Bathory: The Development of Military Art During the Livonian War," in Baltiiskii vopros v kontse XV - XVI vv. Sbornik nauchnykh statei, ed. A. I. FILIUSHKIN (Moscow: Kvadriga, 2010), 106-20; "Introduction" and "Guliai-gorod, Wagenburg, and Tabor Tactics in 16th-17th Century Muscovy and Eastern Europe," in Warfare in Eastern Europe, 1-18, 93-108; "Lisowski's Free Lances: Polish-Lithuanian Mercenaries in Muscovy's Time of Troubles," $R H$ 
42 no.1 (February 2015): 97-113; "Patrick Gordon and the Chudnov-Slobodishche Campaign, 1660," RH 45:1 (2018): 52-69.

Chester S. L. DunNING, "Scottish Soldiers in Early Seventeenth-Century Russia: The Case of George Learmonth and the Belaia Garrison," JISS 7 no. 2 (2014): 23-42.

Richard Hellie, "The Costs of Muscovite Military Defense and Expansion," in The Military and Society, 41-66.

JaRmo Kotilaine, "In Defense of the Realm: Russians Arms Trade and Production in the Seventeenth and Early Eighteenth Century," in The Military and Society, 67-95.

DONALD OSTROWSKI: "Troop Mobilization by the Muscovite Grand Princes (13131533)," in The Military and Society, 19-40; "The Replacement of the Compound Bow by Firearms in the Muscovite Cavalry," in Everyday Life in Russian History, 203-27.

WILLIAM M. REGER IV, “”'European Mercenary Officers and the Reception of Military Reform in the Seventeenth-Century Russian Army," in Modernizing Muscovy, 214-37.

CARol B. Stevens: Russia's Wars of Emergence, 1460-1730 (Harlow: Pearson, Longman, 2007); "Food and Supply: Logistics and the Early Modern Russian Army," in Warfare in Eastern Europe, 119-46.

\section{Cultural History}

\section{Questions}

Was late-fifteenth century Muscovite monastic culture exclusively anti-rational? What was the pace of cultural change in the seventeenth century? How much did seventeenth-century Muscovites know about the "outside world"? What form of communication provided this information? What impact did it have on government policy or elite mentality?

\section{Lacunae}

Romanchuk has not investigated what happened to Kirillo-Belozerskii Monastery pedagogy after 1501. Muscovy remained well-informed of developments among its steppe neighbors in the seventeenth-century such as the Crimea and Kalmyks, but Muscovite access to news on other sedentary states or empires bordering the Eurasian steppe (Ottoman, Safavid, Qing) merits attention equal to that given contacts with Europe.

\section{Summary}

Chrissidis challenges previous scholarship on the Latinophile versus Graecophile cultural factions in the second half of the seventeenth century.

PAul BushKovitch: "Cultural Change among the Russian Boyars 1650-1680: New Sources and Old Problems," FOG 56 (2000), 91-111; “The Vasiliologion of Nikolai Spafarii 
Milescu," RH 36 no. 1 (2009): 1-15; “Change and Culture in Early Modern Russia," Kritika 16 no. 2 (Spring 2015), 291-316;

NIKOLAOS CHRISSIDIS: An academy at the court of the tsars: Greek scholars and Jesuit education in early modern Russia (DeKalb: Northern Illinois University Press, 2016).

ISAIAH GRUBER, "From Bethlehem to Beloozero: Biblical Languages and NationalReligious Boundaries in Muscovy," RH 41 no. 1 (March 2014): 8-22.

Claudia RAE Jensen, Musical cultures in seventeenth-century Russia (Bloomington: Indiana University Press, 2009.

Michael A. Pesenson, "Nicolae Milescu Spafarii's Khrismologion and Kniga o Sivilliakh: Prophesies of Power in Late $17^{\text {th }}$-Century Russia," in Religion and Identity in Russia, 63-80.

ROBERT ROMANCHUK, Byzantine hermeneutics and pedagogy in the Russian North: monks and masters at the Kirillo-Belozerskii Monastery, 1397-1501 (Toronto: University of Toronto Press, 2007).

MARINA Swoboda, "The Furnace Play and the Development of Liturgical Drama in Russia," RR 61 no. 2 (April 2002): 220-34; “The Old Testament 'Apocrypha' in Early Russian Drama," in The Old Testament Apocrypha in the Slavonic Tradition: Continuity and Diversion, ed. LORENZO DiTommaso, SIEGFRIEd BÖTTERLICH, AND MARINA SwOBOdA (Tubingen: Mohr siebeck, 2011), 429-51.

DANiEl C. WAugh: "News Sensations from the Front: Reportage in Late Muscovy concerning the Ottoman Wars," in Rude \& Barbarous Kingdom Revisited, 491-506; "The Best Connected Man in Muscovy? Patrick Gordon's Evidence Regarding News and Communication in Muscovy in the Seventeenth Century," JISS 7 no. 2 (2014): 61-124; "What Was News and How Was It Communicated in Pre-Modern Russia?" in Information and empire mechanisms of communication, 213-52; "What the Posol'skii Prikaz really knew: intelligencers, secret agents and their reports," in Travelling Chronicles: News and Newspapers from the early modern period to the eighteenth century, ed. SIV GORIL BRANDTZAEG, PAUL GORING, AND CHRISTINE WATSON (Leiden: Brill, 2018), 140-55.

DANiEl C. WAUGH AND INGRID MAIER: "How Well Was Muscovy Connected with the World?" FOG 75 (2009): 17-38; "Muscovy and the European Information Revolution: Creating the Mechanisms for Obtaining Foreign News," in Information and empire mechanisms of communication, 77-112. 


\section{Animals}

Questions

Did animals play a different role in Muscovy than in Europe? What kinds of sources breached the wall separating animal from human?

NoRman W. IngHam, "Muscovite Law and The Tale of Ruff son of Russ," RH 34 no. 14 (Spring-Summer-Fall-Winter 2007): 303-14.

Charles J. HALPERIN AND AnN Kleimola, "Beastly Humans and Humanly Beasts in Seventeenth-Century Russia,"Vivliofika 6 (2018): 46-57.

AnN M. KleIMOLA: "Horse Sense: The Emergence of Muscovite Veterinary Medicine," in Moskovskaia Rus', 205-14; “Cultural Convergence: The Equine Connection between Muscovy and Europe," in The Culture of the Horse: Status, Discipline and the Identity in the Early Modern World, ed. KAREN RABER AND TREVA J. TUCKER (New York: Palgrave Macmillan, 2005), 45-62; "Visions of Horses: The Evolution of the Russian Cult of Florus and Laurus," in Mesto Rossii v Evrazii, 86-92; "Hunting for Dogs in $17^{\text {th }}$ century Muscovy," Kritika 11 no. 3 (Summer 2010): 467-88; “Ni pes ni vyzhlets ni gonchaia sobaka: Images of Dogs in Rus,," in Dubitando, 427-42.

MARTha LahanA, 'The Usefulness of Bees in Muscovy,” RH 45 no. 1 (May 2018): 2951.

\section{Abbreviations}

Book of Royal Decrees

The Book of Royal Decrees and the Genesis of Russian Historical Consciousness / "Stepennaia kniga tsarskogo rodosloviia” i genezis russkogo istoricheskogo soznaniia, ed. ANN M. KLEIMOLA AND GAIL LENHOFF (Bloomington: Slavica, 2011).

CASS Canadian-American Slavic Studies / Revue canadienne-américane d'études slaves

CMR Cahiers du monde russe

Dubitando Dubitando. Studies in History and Culture in Honor of Donald Ostrowski, ed. BRIAN J. BOECK, RUSSELl E. MARTIN AND DANIEL B. ROWLAND (Bloomington: Slavica, 2012).

Everyday Life in Russian History 
Everyday Life in Russian History. Quotidian Studies in Honor of Daniel Kaiser, ed. Gary Marker, Joan Neuberger, Marshall Poe and Susan RupP (Bloomington: Slavica 2010).

FOG Forschungen zur osteuropäischen Geschichte

Holy Foolishness in Russia

Holy Foolishness in Russia: New Perspectives, ed. PRISCILla HunT AND SviTlanA KoBETS (Bloomington: Slavica, 2011).

HUS Harvard Ukrainian Studies

Information and empire mechanisms of communication

Information and empire mechanisms of communication in Russia, 1600-1850,

ed. Simon Franklin AND Katherine Bowers (Cambridge: Open Book Publishers, 2017).

Iosif Volotskii and Eastern Christianity

Iosif Volotskii and Eastern Christianity. Essays across Seventeen Centuries, ed. DAVID GOLDFRANK, VALERIA NOLLAN, AND JENNIFER SPOCK (Washington, DC: New Academia Publishers, 2017).

JbfGOE Jahrbücher für Geschichte Ostueropas

JISS Journal of Irish and Scottish Studies

JMH Journal of Modern History

Kritika Kritika: Explorations in Russian and Eurasian History

Letters from Heaven

Letters from Heaven: Popular Religion in Russia and Ukraine, ed. JOHN-PAUL

HIMKA AND ANDRIJ ZAYARNYUK (Toronto: University of Toronto Press, 2006).

Mesto Rossii v Evrazii

Mesto Rossii v Evrazii: sbornik nauchnykh trudov, ed. GYULA SzVÁK (Budapest:

Rossica.Pannonia, 2010).

Modernizing Muscovy

Modernizing Muscovy: Reform and Social Change in Seventeenth-Century Russia, ed. JARMo Kotilaine AND MARSHALl PoE(London: Routledge Curzon, 2004).

Moskovskaia Rus'

Moskovskaia Rus': spetsifika razvitiia / Muscovy: Peculiarities of its

Development, ed. GyUla SzVÁK (Budapest: Magyar Ruszisztikai Intézet, 2003).

The New Muscovite Cultural History 
The New Muscovite Cultural History. A Collection in Honor of Daniel B. Rowland, ed. Valerie A. Kivelson, Karen Petrone, NANCy Shields KollmanN, AND MichaEL FliER (Bloomington: Slavica, 2009).

Novye napravleniia i rezul'taty $v$ rusistike

Novye napravleniia i rezul'taty v rusistike / New Directions and Results in Russistics, ed. GyUla SzvÁK (Budapest: Magyar Ruszisztika Intézet, 2005).

Orthodox Russia

Orthodox Russia: Belief and Practice under the Tsars, ed. VALERIE A. Kivelson AND Robert H. Greene (University Park: Pennsylvania State University Press, 2003).

Religion and Identity in Russia

Religion and Identity in Russia and the Soviet Union. A Festschrift for Paul Bushkovitch, ed. NiKOlAOS CHRISSIDIS, CATHY POTTER, DAVID SCHIMMELPENNINCK VAN DER OYE, AND JENNIFER SPOCK (Bloomington: Slavica, 2011).

RES Revue des Études Slaves

Rusistika Ruslana Skrynnikova

Rusistika Ruslana Skrynnikova. Sbornik statei pamiati professora $R$. G. Skrynnikova, v chest' ego 80-letiia, ed. GyULA SVÁK AND IGOR O. TIUMENTSEV (Budapest-Volgograd: 2011).

RH Russian history / Histoire russe

RR Russian Review

Rude \& Barbarous Kingdom Revisited

Rude \& Barbarous Kingdom Revisited. Essays in Russian History and Culture in Honor of Robert O. Crummey, ed. CHESTER S. L. DunNING, Russell E. MARTIN, AND DANIEL RowLAND (Bloomington: Slavica, 2008).

Seeing Russia Anew

Seeing Muscovy Anew: Politics - Institutions - Culture. In Honor of Nancy Shields Kollmann, ed. VAlerie A. Kivelson, Michael Flier, Daniel ROWLAND, AND ERIKA MONAHAN DOWNS (Bloomington: Slavica, 2017).

$S R$

Slavic Review

The Cambridge History of Russia

The Cambridge History of Russia, v. I, From Early Rus' to 1689, ed. MAUREEN

PERRIE (Cambridge: Cambridge University Press, 2006) 
The Military and Society

The Military and Society in Russia 1450-1917, ed. ERIC LOHR AND MARSHALL

PoE (Leiden: Brill, 2002).

The Military History of Tsarist Russia

The Military History of Tsarist Russia, ed. FREDERICK W. KAGAN AND ROBIN

Higham (New York: Palgrave, 2002).

The State in Early Modern Russia

The State in Early Modern Russia: New Directions, ed. Paul BushKovitch (Bloomington: Slavica, 2019).

States, Societies, Cultures

States, Societies, Cultures East and West. Essays in Honor of Jaroslaw Pelenski, ed. JANusz DuZINKIEWICZ (Editor-in-Chief), Myroslav POPOVyCH, Vladyslav Verstiuk, And Natalia Yakovenko (New York: Ross Publications, 2004).

The Tapestry of Russian Christianity

The Tapestry of Russian Christianity: Studies in History and Culture, ed. NiCHOLAS LUPININ, DONALD OSTROWSKI, AND JENNIFER B. SPOCK (Columbus: The Ohio State University Department of Slavic and East European Languages and Cultures and Resource Center for Medieval Slavic Studies, 2016).

Tobacco in Russian History

Tobacco in Russian History and Culture from the Seventeenth Century to the Present, ed. Matthew P. Romaniello And Tricia Starks (New York: Routledge, Taylor and Francis Group, 2009)

Warfare in Eastern Europe

Warfare in Eastern Europe, 1500-1800, ed. BRIAN DAVIES (Leiden: Brill, 2012). 